\title{
Parent-Subsidiary Communications and the Attorney-Client Privilege
}

\author{
Andrew R. Taggart $\dagger$
}

Suppose an officer of a subsidiary, suspecting that his company has a potential product liability problem, consults the legal staff of the parent corporation. A few years later, after the parent sells the subsidiary to another corporation, consumers begin to suffer injuries from the product and sue the subsidiary, its new parent, and its former parent. May the subsidiary-or its new parent-waive the attorney-client privilege so that, in order to procure a favorable settlement, it can offer the plaintiffs damaging information about the former parent? In other words, has the former parent lost its ability to invoke the attorney-client privilege to halt a disclosure of this sensitive information?'

The few courts to address the issue have held uniformly that the divested subsidiary may unilaterally waive the attorneyclient privilege that would otherwise protect communications that occurred prior to divestment. ${ }^{2}$ Each of these courts has interpreted dictum in the Supreme Court's decision in Commodity Futures Trading Commission $v$ Weintraub ${ }^{3}$ to mandate a formalistic approach that focuses exclusively on who currently controls

$\dagger$ B.A. 1994, Yale University; J.D. Candidate 1998, The University of Chicago.

Outside of the parent-subsidiary context, such agreements to waive have been upheld. See Ohio-Sealey Mattress Manufacturing Co $v$ Kaplan, 90 FRD 21, 26-29 (N D III 1980) (Some members of a group of defendants, sued individually and derivatively, settled their individual suits in exchange for assisting the plaintiff in the litigation against nonsettling defendants, including delivery of documents and waiver of privilege.); Waller $v$ Financial Corp of America, 828 F2d 579, 583-84 (9th Cir 1987) (Settling defendant agreed to cooperate with plaintiffs and was promised a share of the proceeds.).

${ }^{2}$ See Bass Public Limited Co $v$ The Promus Cos, Inc, 1994 US Dist LEXIS 5474, *3 (S D NY) (unpublished magistrate's opinion) (“Bass $I$ "), affd, 868 F Supp 615 (S D NY 1994) ("Bass II"); In re Grand Jury Subpoenas 89-3 and 89-4, 734 F Supp 1207, 1212 (E D Va), affd as United States $v$ Under Seal, 902 F2d 244 (4th Cir 1990); Polycast Technology Corp $v$ Uniroyal, Inc, 125 FRD 47, 50 (S D NY 1989); In re Sealed Case, 120 FRD 66, 70 (N D IIl) (magistrate's opinion), affd, Medcom Holding Co $v$ Baxter Travenol Labs, Inc, 689 F Supp 841 (N D Ill 1988). Although this Comment will focus on waiver by the former subsidiary to the detriment of the parent, the current rule also would allow the former parent to waive against the wishes of the subsidiary. A parent, for example, may choose to waive in order to injure a former subsidiary that has since become a competitor.

${ }^{3} 471$ US 343, 349 (1985). 
the subsidiary. ${ }^{4}$ Even though attorneys or officers of the former parent participated in the communications, these courts held that the former parent does not retain any control over the exercise of waiver. ${ }^{5}$ Thus, in litigation arising after the sale of a subsidiary in which the new parent asserts claims relating to the sale against the former parent, the subsidiary may waive the privilege and give the new parent access to any presale communications between it and agents of the former parent. ${ }^{6}$ Similarly, in a criminal investigation, a subsidiary might, postsale, waive the privilege as part of a settlement agreement with the government. ${ }^{7}$ Presumably a former subsidiary also could waive the privilege as part of a settlement agreement with a plaintiff in a civil case, although no court yet has addressed this issue. ${ }^{8}$

Although these courts are in agreement, the question of how to allocate the authority to waive the attorney-client privilege between a subsidiary and its former parent warrants closer examination. The courts that have addressed the issue have mistakenly interpreted the precedential case law. The rule they have promulgated frustrates the accepted policy goals of the attorneyclient privilege. This issue will become increasingly important as the recent trend for corporations to sell subsidiaries that fall outside of their "core competencies" leads to the breakup and reorganization of many old-style conglomerates. ${ }^{9}$

This Comment explores the allocation of control over the attorney-client privilege regarding predivestment communications between parent, subsidiary, and counsel in the wake of the divestment of a subsidiary. ${ }^{10}$ Part I reviews the case law that es-

4 See Bass I, 1994 US Dist LEXIS 5474 at *4-5; Grand Jury Subpoenas, 734 F Supp at 1210-13; In re Sealed Case, $120 \mathrm{FRD}$ at 70.

' See Bass I, 1994 US Dist LEXIS 5474 at *3-5; Grand Jury Subpoenas, 734 F Supp at 1210-11; Polycast, 125 FRD at 51; Sealed Case, 120 FRD at 70.

${ }^{6}$ See, for example, Bass I, 1994 US Dist LEXIS 5474 at *4-7; Polycast, 125 FRD at 50; Sealed Case, $120 \mathrm{FRD}$ at 68-70.

7 See, for example, Grand Jury Subpoenas, 734 F Supp at 1212 (explaining that former parent "cannot override the [former] subsidiary's waiver" to the government).

${ }_{8}$ The recent Dow Corning breast-implant litigation provides an example of how this scenario might unfold. The plaintiffs are attempting to hold Dow Chemical-Dow Corning's former parent through a joint venture-liable on the theory that it participated in the defective design. See Product Liability: Of Cigarettes and Silicone, The Economist 80 (Mar 22, 1997). Under current law nothing would prevent Dow Corning-currently in bankruptcy-from including waiver of the privilege in a settlement or bankruptcy agreement with the plaintiffs.

9 See, for example, Demergers and Acquisitions: Cut and Paste, The Economist 65 (Feb 1, 1997) (Many large corporate groups are shedding peripheral subsidiaries, while others are acquiring new subsidiaries in their line of business.).

${ }^{10}$ For the purposes of this Comment, "predivestment communications" includes any 
tablished the attorney-client privilege in the corporate context. Part II examines the reasoning of courts that have embraced the unilateral waiver rule and argues that the adoption of this rule rests on a misreading of Weintraub. Part III examines the policy arguments relevant to control of the waiver power. Part IV proposes an improved resolution of the problem-a bilateral control rule. This proposed rule would protect communications shared between parent, subsidiary, and counsel in the same way that the "joint defense" doctrine protects communications shared between parties in anticipation of litigation. A bilateral control rule would not allow either party to waive the attorney-client privilege without the consent of the other.

\section{REVIEW OF CASE LAW}

During the 1980s, the United States Supreme Court made clear that traditional privilege doctrines, developed to handle communications between individuals, must be updated to accommodate new corporate structures. ${ }^{11}$ Lower courts have followed the Court's lead in effectuating the goals of the attorneyclient privilege. However, the handful of courts addressing the specific question of control over the privilege as between subsidiary and former parent have departed from the Court's pragmatic approach. Instead, they have reasoned that, because the former subsidiary is now an independent corporate entity, the subsidiary necessarily is vested with unilateral control of the power to waive the privilege.

\section{A. The Evolution and Scope of the Corporate Privilege}

Often recognized as the oldest and strongest of the common law privileges, ${ }^{12}$ the attorney-client privilege protects communications made while seeking legal advice. ${ }^{13}$ However, these com-

attorney-client privileged material generated in the presence of officers (including corporate counsel) of both the parent and its subsidiary.

"See Upjohn Co $v$ United States, 449 US 383, 392 (1981) (recognizing that "[i]n light of the vast and complicated array of regulatory legislation confronting the modern corporation," corporations must be afforded broad attorney-client privileges); Weintraub, 471 US at 348 (noting the complexities of the corporate attorney-client privilege).

${ }_{12}$ Upjohn, 449 US at 389, citing John H. Wigmore, 8 Evidence in Trials at Common Law $\S 2290$ at 542 (Little, Brown 1961). For a definition of the privilege, see Wigmore, 8 Evidence $\$ 2292$ at 554 (explaining that where legal advice of any kind is sought from a professional legal advisor in his capacity as such, the communications relating to that purpose, made in confidence by the client, are protected from disclosure by himself or by the legal advisor).

${ }^{13}$ John W. Strong, ed, McCormick on Evidence $\S 88$ at 322 (West 4 th ed 1992) (ex- 
munications must be confidential for the privilege to apply; the privilege is destroyed if outsiders are present at a meeting or documents are disseminated to them. ${ }^{14}$ Moreover, the privilege does not protect the facts underlying the attorney-client discussion; it only protects the substance of the discussion itself. ${ }^{15} \mathrm{Fi}$ nally, the privilege can be pierced if the communications were intended to further crime or fraud. ${ }^{16}$

The Supreme Court extended the privilege to corporate entities as early as $1915 .{ }^{17}$ In its 1981 decision in Upjohn Co $v$ United States ${ }^{18}$ the Court reaffirmed the application of the privilege to corporations. The Upjohn Court explained that the primary policy goal of the corporate privilege is to encourage legal consultation within the corporation, thus furthering compliance with the law. ${ }^{19}$ The corporation's management, rather than the individuals who took part in the communications, control the privilege. ${ }^{20}$ If a corporation merges with another corporation, the surviving entity controls the privilege.$^{21}$ However, if a corporation merely sells its assets, it retains full control of the privilege for communications related to those assets. ${ }^{22}$

plaining that the client must be seeking advice).

${ }^{14}$ Id \$ 91 at 333-38 (discussing the need to maintain confidentiality).

${ }^{15}$ Id $\$ 90$ at $330-31$ (explaining that the fact of the consultation is not privileged). See also Upjohn, 449 US at 395 (noting the distinction between a fact and a communication concerning a fact); John William Gergacz, Attorney-Corporate Client Privilege \$ 3.02[2][c][i] at 3-41 to 3-42 (Garland 2d ed 1990) (Communication itself is protected but the facts underlying the communication are not.).

${ }^{16}$ Strong, ed, McCormick on Evidence $\S 95$ at 134 (cited in note 13) (discussing the "crime-fraud" exception). See generally Revised Uniform Evidence Rules $\$ 502$ (1986) (delineating the privilege's requirements). Under the Federal Rules of Evidence, privileges are governed by the law-state or federal-that supplies the rule of decision. FRE 501.

${ }^{17}$ See United States $v$ Louisville \& Nashville Railroad Co, 236 US 318, 336 (1915) (noting that the privilege encourages corporations to seek legal advice and assistance).

${ }^{18} 449$ US 383, 389-90 (1981) (noting that the Court previously had assumed that the privilege attached to corporations and that the government had not contested the issue). See also Weintraub, 471 US at 348 ("It is by now well established . . . that the attorneyclient privilege attaches to corporations as well as to individuals."); John E. Sexton, $A$ Post-Upjohn Consideration of the Corporate Attorney-Client Privilege, 57 NYU L Rev 443, 444 (1982) ("[T] cal purposes, now settled.").

${ }^{19}$ See 449 US at 392. See also text accompanying notes 107-12.

${ }^{2}$ See, for example, Chronicle Publishing Co $v$ Hantzis, 732 F Supp 270, 273 (D Mass 1990) ("The power to invoke or waive a corporation's attorney-client privilege may be asserted only by current corporate management."); In re Grand Jury Proceedings, $434 \mathrm{~F}$ Supp 648, 650 (E D Mich 1977) (explaining that "the privilege is and should remain that of the company and not that of the communicating officer").

${ }^{21}$ See, for example, O'Leary v Purcell Co, Inc, 108 FRD 641, 644 (M D NC 1985) (allowing surviving corporation to assert the merged company's privilege); Chronicle, $732 \mathrm{~F}$ Supp at 271 n 2 (same).

${ }^{2}$ See NL Industries, Inc $v$ Koomey, Inc, 647 F Supp 936, 936 (S D Tex 1984) (Assign- 


\section{B. Predivestment Communications Between Parents and Subsidiaries}

Courts' treatment of communications involving officers or counsel from both parent and subsidiary is grounded in the complex doctrines surrounding communications between two or more legal entities. ${ }^{23}$ Ordinarily, the attorney-client privilege exists between a single entity (such as a corporation) and its counsel. The presence of outsiders at the discussion typically destroys the privilege through the loss of confidentiality. ${ }^{24}$ The vast majority of courts, however, have held that communications between a parent and a subsidiary retain their confidential nature despite the fact that each party is a discrete legal entity. ${ }^{25}$

Most courts that have done so have not explained the reasoning behind their decisions. They also have failed to articulate the rule governing the exercise of waiver power for such shared communications. ${ }^{26}$ This imprecision is only natural, since waiver

ment of patent does not transfer the attorney-client relationship.); Sobol $v$ EP Dutton, Inc, 112 FRD 99, 103 (S D NY 1986) (Transfer of book rights accompanied by legal files does not transfer control of privilege for those files.); NCL Corp v Lone Star Building Centers (Eastern) Inc, 144 Bankr 170, 173-74 (Bankr S D Fla 1992) (explaining that, after the sale of the majority of its assets and name to one corporation, the seller retained the privilege).

${ }^{23}$ Wigmore's comment still holds true in this area: "The rulings, however, cannot well be arranged under the appropriate heads, inasmuch as their reasoning is often loosely or obscurely stated." Wigmore, 8 Evidence $\$ 2312$ at 604 n 3 (cited in note 12).

${ }^{24}$ See Strong, ed, McCormick on Evidence $\$ 91$ at 333-34 (cited in note 13).

${ }^{25}$ See, for example, Admiral Insurance Co $v$ United States District Court, 881 F2d 1486, 1493 n 6 (9th $\mathrm{Cir} 1989$ ) (noting in dicta that communications between employees of a subsidiary and corporate counsel for the parent would be protected); Glidden Co $v$ Jandernoa, 173 FRD 459, 472 (W D Mich 1997) ("The universal rule of law, expressed in a variety of contexts, is that the parent and subsidiary share a community of interest, such that the parent (as well as the subsidiary) is the 'client' for purposes of the attorney-client privilege."); In the Matter of Interco Inc, 137 Bankr 1008, 1010 n 1 (Bankr E D Mo 1992) (After noting that the general counsel considered his client to be "the entire Interco organization," the court proceeded to discuss the waiver issue despite the fact that counsel was an officer of the parent while the communicating parties were officers of the subsidiary.); United States $v$ AT\&T Co, 86 FRD 603, 616 (D DC 1979) (treating all wholly-owned and majority-owned subsidiaries as part of a single corporate client); United States $v$ United Shoe Machinery Corp, 89 F Supp 357, 359 (D Mass 1950) (defining "client" to include all affiliates and subsidiaries). Compare Bowne of New York City, Inc $v$ AmBase Corp, 150 FRD 465, 491 (S D NY 1993) (noting that separate representation of parent and subsidiary in divestiture transaction demonstrated lack of common interest).

${ }^{26}$ While many courts rely on the cormmon interest or joint client doctrines discussed below to reach this result, others merely assume that the necessary confidentiality is maintained. See Yorke v Santa Fe Industries, Inc, 121 Bankr 794, 799 (Bankr N D IIl 1990) (relying on joint client rule because parent and subsidiary shared the same counsel); Glidden, 173 FRD at 473 (finding that fiduciary relationship between parent and subsidiary meant that there could be no expectation of confidentiality between the parties, that there was a "complete community of interest" between them, and that therefore 
is not ordinarily pertinent when a parent and a subsidiary share communications; the parent can control the subsidiary's decision to exercise waiver. However, once the subsidiary is no longer controlled by the parent, the choice of a rule governing the waiver of the privilege for such shared communications becomes critical.

Traditionally, courts have allowed an exception to loss of confidentiality for shared communications that occurred in connection with anticipated or pending litigation. The so-called "joint defense" doctrine requires that both parties consent to a waiver of the privilege before it can be used against them by a third party. ${ }^{28}$ However, the attorney-client privilege may not later be invoked if the two parties, formerly joint defendants, become adversaries in subsequent litigation. ${ }^{29}$ The same waiver rule governs situations in which the parties share the same counsel-that is, "joint client" situations. ${ }^{30}$ Because both parties

the "subsidiary and parent [were] joint clients, each of which ha[d] an interest in the privileged communications").

${ }^{27}$ In the past, the term "joint defense" doctrine was used interchangeably with the term "common interest" rule. However, these two doctrines are no longer identical. Thus, interchangeable usage is no longer appropriate. See text accompanying notes 32-36.

${ }^{23}$ See John Morrell \& Co v Local Union 304 A, 913 F2d 544, 556 (8th Cir 1990) (principle of forbidding waiver to a third party without consent is "fundamental"); In re Madison Management Group, Inc $v$ Zell, 1997 Bankr LEXIS 1515, *11 (Bankr N D Il) (forbidding waiver by debtor, a former subsidiary of parent, to a third party for joint defense material); Ohio-Sealy, 90 FRD at 29 ("That these documents included communications from settling defendants to their individual attorneys does not alter the fact that the documents reflect the joint defense effort engaged in by the defendants. For this reason, the settling defendants cannot unilaterally waive the attorney-client privilege that attached thereto."); Western Fuels Association, Inc v Burlington Northern Railroad Co, 102 FRD 201, 203 (D Wyo 1984) ("[W]aiver of privileges, relating to information shared in joint defense communications by one party to such communications will not constitute a waiver by any other party to such communications. This limitation is necessary to assure joint defense efforts are not inhibited or even precluded by the fear that a party to joint defense communications may subsequently unilaterally waive the privilege of all participants, either purposefully in an effort to exonerate himself, or inadvertantly.") (citation omitted).

${ }^{29}$ See In re a Grand Jury Subpoena Duces Tecum, 406 F Supp 381, 394-95 (S D NY 1975) ( $[$ [C]onfidences shared by joint defendants and their counsel are effectively shielded against outside access. . . . [T] [hat shield may be lowered only when the parties once joined assume the stance of opposing parties in subsequent litigation."); Ohio-Sealy, 90 FRD at 27 (" $[T]$ he joint defense privilege cannot be waived without the consent of all parties to the defense, except in the situation where one of the joint defendants becomes an adverse party in a litigation."). See also Metro Wastewater Reclamation District $v$ Continental Casualty Co, 142 FRD 471, 479-80 (D Colo 1992) (Even if plaintiffs were engaged in a joint defense, there could be no expectation of confidentiality as to the defendant insurance carriers since the communications involved litigation against the EPA in which plaintiffs and defendants had identical interests. Therefore, production of documents to defendant would not violate the privilege.); Sexton, 57 NYU L Rev at 510-12 (cited in note 18).

${ }^{30}$ See Wigmore, 8 Evidence $\S 2312$ at 603 (cited in note 12) ("Here the communica- 
must approve a waiver, this Comment refers to this rule as the "bilateral control" rule.

While the joint defense rule originated in the defense of criminal prosecutions, it has been expanded to cover civil litigation and communications preceding imminent litigation. ${ }^{31}$ It also allows parties who do not have a direct interest in the matter to communicate if they share a "common legal interest."32 Lastly, the doctrine has been stretched to accommodate necessary discussions regarding transactions, not just litigation. ${ }^{33}$ During the expansion of the joint defense doctrine, it has become unclear whether the bilateral control rule applies to these new situations. At least one commentator has argued that joint defense situations may be distinguished from the common interest doctrine. ${ }^{34}$ The common interest doctrine maintains confidentiality between the communicating parties and bars assertion of the privilege in direct litigation between them. ${ }^{35}$ Unlike the joint defense doc-

tions are clearly privileged from disclosure at the instance of a third person. Yet they are not privileged in a controversy between the two original parties, inasmuch as the common interest and employment forbade concealment of one from the other."); id § 2328 at 639 (cited in note 12) (The "waiver should be joint for joint statements."). In complex corporate situations, the difference between the common interest and joint client distinctions have become blurred. See Charles Alan Wright and Kenneth W. Graham, Jr., 24 Federal Practice and Procedure $\S 5493$ at 99 (West Pkt Pt 1997) (The two concepts have become "mangled.").

${ }^{31}$ See, for example, Under Seal, 902 F2d at 249 ("Whether an action is ongoing or contemplated, whether the jointly interested persons are defendants or plaintiffs, and whether the litigation or potential litigation is civil or criminal, the rationale for the joint defense privilege remains unchanged: Persons who share a common interest in litigation should be able to communicate with their respective attorneys and with each other to more effectively prosecute or defend their claims."). For an overview of the disagreement of courts on the scope of the joint defense and common interest doctrines, see United States $v$ Weissman, 1996 US Dist LEXIS 19066, *19-36 (S D NY).

${ }^{32}$ Roberts v Carrier Corp, 107 FRD 678, 688 (N D Ind 1985) (finding no waiver from communication between sibling corporations because both shared a common legal interest in resolving product liability issue); Duplan v Deering Milken, 397 F Supp 1146, 1175 (D SC 1974) (Identical, not merely similar, community of legal interests will prevent waiver; legal interests defined as cases of legal duty or direct transactions between parties); Rayman $v$ American Charter, 148 FRD 647, 654 (D Neb 1993) (noting that the meaning of common legal interest and anticipation of litigation is not clear).

${ }^{33}$ See Hewlett-Packard v Bausch \& Lomb, 115 FRD 308, 309-11 (N D Cal 1987) (finding no waiver when seller disclosed to the buyer legal issues the buyer might face if the sale were consummated). The court based its ruling both on the common interest between the parties and on the policy goal of encouraging open business transactions. See also Rayman, 148 FRD at 654 (finding common legal interest when seller informed potential buyer of legal issues that the buyer would confront if the corporate merger were completed).

${ }^{34}$ See John T. Hundley, White Knights, Pre-Nuptial Confidences, and the Morning After: The Effect of Transaction-Related Disclosures on the Attorney-Client and Related Privileges, 5 DePaul Bus L J 59, 82-85 (1992/1993).

${ }^{35}$ See note 29 and accompanying text. 
trine, however, the common interest doctrine allows waiver to a third party without the consent of the party against whom the information will be used. ${ }^{36}$ This Comment refers to this concept as the "unilateral control" rule because either party may unilaterally waive the privilege. Courts following the unilateral control rule for the parent-subsidiary conflict have chosen to assume that all communications between a parent and a subsidiary remained confidential. However, they have ruled that the narrow portion of such communications that clearly represents a joint defense effort is covered by the bilateral rule. The unilateral control rule governs waivers for the remainder. ${ }^{37}$

\section{Weintraub and the Exercise of Waiver}

Courts advocating the unilateral control rule in the divested subsidiary context have relied on Weintraub. ${ }^{38}$ In Weintraub, a corporation under investigation by the Commodity Futures Trading Commission filed for bankruptcy under Chapter 7 of the Bankruptcy Code and the court appointed a trustee. Counsel for the corporate debtor invoked the privilege on behalf of the corporation for prepetition communications. At the request of the Commission, the trustee waived the privilege. A director of the corporation who was still on the board and who had served at the time of the communication challenged the trustee's power to waive the corporate debtor's privilege. The Seventh Circuit held that the trustee could not waive the privilege for prepetition communications. ${ }^{39}$

Before reversing, the Supreme Court first summarized the parties' concessions concerning the prevailing law:

The parties in this case agree that, for solvent corporations, the power to waive the corporate attorney-client privilege

${ }^{36}$ See Metro Wastewater, 142 FRD at 479.n 7 ("The distinctions between the two doctrines relate to the timing of disclosure and the ability thereafter to waive the privilege."); Graco Children's Products, Inc v Dresller, Goldsmith, Shore \& Milnamow, 1995 US Dist LEXIS 8157, *13-17 (N D Ill) (unpublished decision) (discussing separately whether communications were protected by either "community of interests" or joint defense).

${ }^{37}$ Under Seal, 902 F2d at 250 (upon divestiture, subsidiary could unilaterally waive privileges for all documents, but court overruled lower court as to material caused by the joint-defense doctrine); Medcom Holding, 689 F Supp at $844-45$ (unilateral waiver for all materials except for joint defense, which required consent of former parent); Polycast, 125 FRD at 51 (finding joint privilege between parent and subsidiary, but allowing unilateral waiver since communications were not covered by joint defense privilege); Bass $I I, 868 \mathrm{~F}$ Supp at 619 (same).

${ }^{33} 471$ US at 349.

${ }^{39}$ See id at 345-47. 
rests with the corporation's management and is normally exercised by its officers and directors. . . . The parties also agree that when control of a corporation passes to new management, the authority to assert and waive the corporation's attorney-client privilege passes as well. New managers installed as the result of a takeover, merger, loss of confidence by shareholders, or simply normal succession, may waive the attorney-client privilege with respect to communications made by former officers and directors. Displaced managers may not assert the privilege over the wishes of current managers .....$^{40}$

Given this framework, the Court had to decide which party should control the privilege rights of a single entity: a current director of the corporate debtor or the bankruptcy trustee. ${ }^{41} \mathrm{Be}$ cause the Bankruptcy Code severely limited the directors' management authority-shifting it instead to the trustee-the Court analogized the trustee to new management, and thus held that the trustee controlled the privilege. ${ }^{42}$ The Court also noted that the purpose of the Bankruptcy Code would be frustrated if trustees could not access privileged material to uncover malfeasance. ${ }^{43}$

Lower courts have applied Weintraub's reasoning to a variety of similar situations in which competing parties purported to control the privilege for a single entity. Several of these cases arose out of the Savings and Loan ("S\&L") crisis when statutorily empowered government agencies took over insolvent S\&Ls. These agencies tried to defeat assertions of the privilege by the directors of the S\&Ls, who wished to use the privilege to protect themselves. ${ }^{44}$ Courts found that these agencies could control the

${ }^{4}$ Id at 348-49 (citations omitted). None of the above situations was present in the underlying action, and subsequent courts have recognized that the statement is dictum. See note 56.

${ }^{41}$ See id at 349.

${ }^{42}$ See id at 352-53.

${ }^{43}$ See id at 353-54 (noting that the trustee must investigate the situation in order to fulfill his duty to maximize the estate and that the crime-fraud exception provides inadequate tools for fulfilling this duty). See also 11 USC \$§ 547-48, 704(4) (1994) (describing the duties of the trustee, including investigation of the debtor's financial affairs). The Court rejected the argument that the crime-fraud exception would provide adequate tools to the trustee. See Weintraub, 471 US at 354.

4 See In re Financial Corp of America, 119 Bankr 728, 736-37 (Bankr C D Cal 1990) (A federal agency appointed as a receiver inherits the attorney-client privilege of an insolvent S\&L, and may expressly retain it in any subsequent transfer.); FDIC $v$ Cherry, Bekaert \& Holland, 131 FRD 202, 205 (M D Fla 1990) (FDIC has statutory authority under S\&L statute to assert control of institution's waiver power.); Odmark $v$ Westside Ban- 
privilege when they acted as receivers but not when they acted in their corporate capacity as buyers of assets. ${ }^{45}$ One court recently applied the same distinction to the appointment of an equitable receiver to manage a corporation's affairs. ${ }^{46}$

\section{Cases Applying the Unilateral Control Rule in the Divested Subsidiary Context}

Four courts have addressed whether a divested subsidiary has the unilateral power to waive the attorney-client privilege for predivestment communications. ${ }^{47}$ In these cases, unlike Weintraub and its progeny, two entities were involved in the privileged communications. All four courts held that the subsidiary, and thus the new parent, could unilaterally waive the privilege. ${ }^{48}$

In three of the cases, the buyer of the subsidiary sued the seller and sought to obtain privileged predivestment communications. ${ }^{49}$ The fourth case, the first to reach a federal appellate court, concerned a criminal investigation of both the subsidiary and its former parent. ${ }^{50}$ The case involved an interesting twist: the divested subsidiary once had been a division of the parent corporation. Some of the parent's privileged material was placed in the records of the division before its incorporation as a subsidiary. Predivestment communications took place over time, and the subsidiary later was divested. The subsidiary then waived its

corporation, Inc, 636 F Supp 552, 555 (W D Wash 1986) (analogizing relevant statutes to use of bankruptcy statutes in Weintraub and holding that FSLIC controlled the waiver power while acting as receiver).

is See, for example, FDIC $v$ McAtee, 124 FRD 662, 664 (D Kan 1988) (FDIC, when acting in "corporate capacity" instead of as a receiver, cannot control privilege.).

${ }^{46}$ See Commodity Futures Trading Commission v.Standard Forex, 882 F Supp 40, 43 \& $\mathrm{n} 2$ (E D NY 1995) (granting receiver this power upon a showing of "some valid reason why the receiver needs to control" the privilege).

${ }^{47}$ See Bass $I_{3} 1994$ US Dist LEXIS 5474; Grand Jury Subpoenas, 734 F Supp 1207; Polycast, 125 FRD 47; Sealed Case, 120 FRD 66 (magistrate's opinion). See also Madison Management Group, 1997 Bankr LEXIS 1515 at *11 (forbidding trustee of former subsidiary from waiving privilege to third party against wishes of former parent, apparently assuming that the material was covered by the joint defense privilege).

${ }^{48}$ See Under Seal, 902 F2d at 248; Bass II, 868 F Supp at 620-21; Polycast, 125 FRD at 49-50; Medcom Holding, $689 \mathrm{~F}$ Supp at 844.

${ }^{4}$ See Bass II, 868 F Supp at 620; Polycast, 125 FRD at 49-50; Medcom Holding, 689 F Supp at 844. Note, however, that the form of the transaction in Bass complicated that court's analysis. There, the seller shifted a large portion of his business into a new subsidiary, and then merged the original corporation into a subsidiary owned by the buyer. The survivor then became a subsidiary of the buyer. The subsidiary created by the "seller" was the opposing party to the buyer. Since the seller's remaining business continued under the same management, headquarters, and shareholders as before, the practical differences were small. Bass $I I, 868$ F Supp at 617.

${ }^{50}$ See Under Seal, 902 F2d at 248. 
privilege at the request of the government, which was conducting a criminal investigation. The trial court had held that the unilateral control rule applied to the parent-subsidiary material, but left unresolved whether the parent retained sole control of the privilege for material generated while the business was a division. ${ }^{51}$ The possible privilege as to the latter material was waived by a lack of confidentiality, for the parent permitted the newly independent subsidiary to retain those documents. ${ }^{52}$ The Fourth Circuit affirmed without specifically discussing the distinction between a division and a subsidiary. ${ }^{53}$

Courts adopting the unilateral control rule agree on several principles. First, they assume that the presence of officers of both corporations does not destroy the privilege through a loss of confidentiality. ${ }^{54}$ Second, they find that the subsidiary can unilaterally waive the privilege for predivestment communications, even if this action is against the wishes of the former parent. ${ }^{55}$ Third, they conclude that the Supreme Court's opinion in Weintraub is persuasive and rely on it for the proposition that the new owners must have total control of the privilege. ${ }^{56}$

Just as the Weintraub Court stated in dicta that managers displaced by a takeover lose control of the privilege, these courts hold that the old parent loses control once it sells the corporation. ${ }^{57}$ The subsidiary's relationship with the former parent is irrelevant. For these courts, the unilateral control rule best honors the principle of Weintraub by allowing the current managers of

${ }^{51}$ See Grand Jury Subpoenas, 734 F Supp at 1212-13.

${ }^{82}$ See id. This decision, which seems to contradict other courts' holdings about confidentiality, illustrates an overly formalistic application of the unilateral control rule.

s3 See Under Seal, 902 F2d at 248.

st See Bass I, 1994 US Dist LEXIS 5474 at *3-5; Grand Jury Subpoenas, 734 F Supp at 1212; Polycast, 125 FRD at 49-50; Medcom Holding, 689 F Supp at 844.

${ }^{s s}$ See Bass II, 868 F Supp at 620-21; Grand Jury Subpoenas, 734 F Supp at 1209-10, 1212; Polycast, 125 FRD at 49-50; Sealed Case, 120 FRD at 70.

${ }^{s 6}$ See, for example, Bass I, 1994 US Dist LEXIS 5474 at *3, 4 (Party arguing against waiver "chooses to ignore certain realities concerning the corporate form which were summarized by the Supreme Court."); Grand Jury Subpoenas, 734 F Supp at 1211 ("The principle of Weintraub, therefore, is that invoking or waiving a corporation's privilege is an incident of control of the corporation."), affd as Under Seal, 902 F2d at 248 ("While this statement in the context present here is dictum, and perhaps might have been in Weintraub, nevertheless it is a consideration of the subject at hand by the highest authority, and we find it persuasive."); Polycast, $125 \mathrm{FRD}$ at 51 (quoting passage from Weintraub prior to announcing holding); Medcom Holding, 689 F Supp at 844 (rejecting attempt to distinguish Weintraub because Weintraub expressly included takeovers and mergers in its findings that new corporate managers may waive).

${ }^{57}$ See Weintraub, 471 US at 349 . See also note 69 and accompanying text. 
all parties participating in the communications to waive the privilege. ${ }^{58}$

Importantly, all of the courts applying the unilateral control rule to the divested subsidiary situation (the "unilateral control" courts) recognize that some parent-subsidiary communications still may be protected. If the communications meet the requirements of the joint defense doctrine, the subsidiary cannot unilaterally waive the privilege to provide evidence of the communications to the new parent ${ }^{59}$ or a third party such as the government. ${ }^{60}$ However, even under the joint defense privilege, neither the parent nor the former subsidiary can invoke the privilege during direct litigation with each other. ${ }^{61}$

\section{The UNILATERAL CONTROL RULE IS NOT MANDATED BY PRECEDENT}

The unilateral control cases rest on two propositions. First, the courts agree that predivestment communications, even when unrelated to anticipated or current litigation between related corporations, are nevertheless privileged under the common interest doctrine. ${ }^{62}$ Second, because the common interest doctrine provides that either party may waive the privilege, Weintraub implies that on divestment of a subsidiary, the subsidiary may exercise this power. ${ }^{63}$ Thus, lower courts have interpreted Weintraub as barring a requirement of mutual consent before the privilege can be waived. ${ }^{64}$

The justifications offered by courts in support of the unilateral control rule suffer from a number of deficiencies. First, these courts misinterpret the Supreme Court's reasoning in Weintraub. The broad passage on which they rely does not preclude adopting the bilateral control rule in the subsidiary context and is, in any case, dictum. Second, the courts' approaches are formalistic

${ }^{s 8}$ See text accompanying note 70 . The Bass $I$ court held in the alternative that the parties could have contracted around unilateral control. 1994 US Dist LEXIS 5474 at *6. See also note 96.

${ }^{\text {so }}$ See Bass $I I, 868 \mathrm{~F}$ Supp at 621 (finding the joint defense privilege inapplicable); Polycast, 125 FRD at 50-51 (same); Medcom Holding, 689 F Supp at 845-46 (applying the doctrine to shield material).

${ }^{\infty}$ See Under Seal, 902 F2d at 249-50 (overruling the trial court's decision not to allow the joint defense privilege to block waiver to government).

${ }^{61}$ See text accompanying note 29.

${ }^{62}$ See text accompanying notes $31-34$ and 54.

See text accompanying note 55 .

64 The opposite rule, which would require mutual consent, was earlier described as a "bilateral control" rule. See text accompanying notes 28-36. 
rather than tailored to the realities of the corporate context; as such, they fail to advance the policy goal of encouraging corporate communication identified by the Supreme Court in Upjohn. ${ }^{65} \mathrm{Fi}$ nally, these cases cannot be justified as fulfilling the wishes of the contracting parties in the initial transaction that divested the subsidiary. To the contrary, the parties would most likely contract for some form of bilateral control of the waiver power. However, transaction costs may well prevent parties from addressing the issue of waiver at the time of the contract. ${ }^{66}$

\section{A. Inapplicability of Weintraub in the Divested Subsidiary Context}

The courts that have permitted unilateral waiver of the privilege in the divestment context cite Weintraub as authority. The passage at issue states:

New managers installed as the result of a takeover, merger, loss of confidence by shareholders, or simply normal succession, may waive the attorney-client privilege with respect to communications made by former officers and directors. Displaced managers may not assert the privilege over the wishes of current managers . . . .67

The Fourth Circuit, referring to this excerpt, stated that "[w] perhaps may have been in Weintraub, nevertheless it is a consideration of the subject at hand by the highest authority, and we find it persuasive." ${ }^{\prime 68}$ However, the fact pattern in Weintraub is fundamentally different from those that arise in the divestiture context. In addition, a presumption of wrongdoing unites the cases that the Court discussed in Weintraub; in the divested subsidiary context, there is no such presumption. Third, the unilateral control rule leads to a situation in which the application of the privilege depends not on the policy goals articulated by the Court, but rather on the mechanics of the corporation's chosen structure. This result seems to contradict the pragmatism in

${ }^{6}$ See $U p j o h n, 449$ US at 390-92 (explaining that the privilege protects the exchange of information).

${ }_{66}$ Transaction costs probably will prevent the parties from addressing the issue of control of the attorney-client privilege. Even if the parties are aware of the handful of recent unilateral cases - a doubtful proposition-the likelihood that a waiver situation will develop is small, so that the incentive to incur extra negotiating costs to address the issue is low.

67 471 US at 349.

Under Seal, 902 F2d at 248. 
Weintraub that the unilateral control courts found persuasive. Taken together, these factors suggest that it is inappropriate to apply Weintraub to the divestiture context.

\section{Ordinary meaning of the text.}

The text of this dictum does not mandate a unilateral control rule in the divested subsidiary context. To the contrary, the plain meaning of the text excludes its application to these cases. Several of the courts analogize the sale of subsidiaries in their cases to the "takeover," "merger," and "normal succession" scenarios discussed in Weintraub ${ }^{69}$ One court used the passage to support the principle that management must be allowed to control the privilege for the benefit of the stockholders, including the new parent that gained control by purchasing the subsidiary's stock. ${ }^{70}$

These readings of Weintraub are questionable insofar as they fail to recognize that the Weintraub Court limited its discussion to managers who had been "displaced," which in ordinary language suggests the use of force. ${ }^{71}$ This language does not embrace the type of voluntary transactions that precede the transfer of a subsidiary. A management group forced out after a takeover, merger, or loss of shareholder confidence certainly is "displaced." ${ }^{.72}$ A vote of the board could also "displace" a CEO through "normal succession." But if a corporation divests a subsidiary, it is difficult to see how it has "displaced" itself. Instead, it has engaged in a voluntary arm's length transaction with the purchaser of the subsidiary. Unlike the situation in Weintraub, the sale of a subsidiary involves no overt external pressure; thus, this kind of sale more properly falls outside of the Court's "displacement" language.

A second oversight in the unilateral control courts' reading of Weintraub is their failure to recognize that the conversations at

69 See Sealed Case, 120 FRD at 68 ("Takeovers, and many if not most mergers, involve changes of ownership."), affd, Medcom Holding, 689 F Supp at 844 ("takeovers and mergers"); Grand Jury Subpoenas, 902 F2d at 248 ("change of management in the normal course of business").

${ }^{70}$ See Grand Jury Subpoenas, 734 F Supp at 1211.

71 "Displace" is defined as: "To crowd out; to take the place of." Black's Law Dictionary 471 (West 6th ed 1990). See also Random House Dictionary of the English Language 568 (2d ed 1987) (defining "displace" as "to compel," "put out of usual or proper place, take the place of, replace, supplant," "to rid oneself of"). All of these definitions imply an element of external force acting on the party that is displaced.

72 The Court may have been influenced by the knowledge that after a takeover managers are often replaced. See Frank H. Easterbrook and Daniel R. Fischel, The Economic Structure of Corporate Law 162 (Harvard 1991) ("Within three years of an acquisition, half of all managers at targets are out of work."). 
issue in Weintraub involved one entity (and its counsel), whereas communications in the divested subsidiary context involve two entities (and their counsel). In Weintraub, the party who controlled the entity at a given point in time-the bankruptcy trustee or the new directors-controlled the privilege. Weintraub did not involve a multi-entity situation-when two separate legal entities are present at the time of communication-and thus cannot be read to adopt a rule that either entity should have the ability to waive against the wishes of the other. The Court merely set forth a rule providing that ousted individuals could not exercise the privilege. The fact that such individuals had been privy to those communications was irrelevant; they participated in the conversations only in their capacity as agents of the corporation. ${ }^{73}$ However, when a parent engages in privileged communications involving its subsidiary, it does not participate solely (or even partly) as an agent of the subsidiary. Rather, the parent is an independent entity with its own interest in protecting the communications.

2. Divestment of a subsidiary does not involve a heightened suspicion of wrongdoing.

Another indication that Weintraub does not compel the unilateral control rule is that, in the divested subsidiary context, there is no need to ferret out wrongdoing. In fashioning the attorney-client privilege in the corporate area, federal courts have been especially sensitive to the need to preclude parties from using the privilege as a shield for wrongdoing. Indeed, all of the situations examined by the Weintraub Court raise a suspicion of such behavior. ${ }^{74}$ Divestment of a subsidiary, by contrast, is in no sense a natural sign of wrongdoing. ${ }^{75}$

When courts reject parties' assertions of privilege, they often base their rejection on a suspicion of wrongdoing. The Weintraub Court, although focusing on the statutory role of the bankruptcy trustee, also expressed concern about the privilege's potential to

${ }^{23}$ See text accompanying note 20.

" See Vincent C. Alexander, The Corporate Attorney-Client Privilege: A Study of the Participants, 63 St John's L Rev 191, 362 (1989) ('The Supreme Court's reasoning . . . supports the view that when management, charged with its own wrongdoing, may be motivated to exercise the corporation's privilege primarily in its own self-interest, someone other than existing management should determine the privilege question.").

${ }^{75}$ To be sure, one can imagine a strategic sale designed to insulate the seller from anticipated liability. Nevertheless, the specter of wrongdoing is far less than in a hostile takeover, bankruptcy, or derivative suit. 
cloak wrongdoing. ${ }^{76}$ Similar concerns are present when the government takes over troubled S\&Ls. ${ }^{77}$

Such suspicions also arise when an individual, usually a former officer, attempts to assert the privilege over a corporate waiver. As commentators have pointed out for decades, it is extremely difficult to force out corporate management. ${ }^{78}$ If a hostile takeover, merger, proxy fight, or vote by the board actually displaces management, this may well suggest that something has gone wrong. The corporation would therefore want unfettered access to and control over all privileged information. This suspicion may explain courts' decisions to grant control of the privilege to current management and forbid former officers from invoking it, even when these former officers were party to the communications. ${ }^{79}$

A similar rationale underlies the rule that shareholders may waive the privilege in derivative suits - even if management has asserted it-if the shareholders can show good cause.$^{80}$ Because a plaintiff must surmount numerous hurdles in order to force a corporation to pursue a derivative suit, ${ }^{81}$ it is natural to infer

${ }^{76}$ See Weintraub, 471 US at 353-54, citing 11 USC $\$ \S 547-48,704(4)$ (1994) ("The Code's goal of uncovering insider fraud would be substantially defeated if the debtor's directors were to retain the one management power that might effectively thwart an investigation into their own conduct."). See also Donald P. Board, Review Essay: Retooling "A Bankruptcy Machine that Would Go Of Itself", 72 BU L Rev 243, 264 (1992) ("One can imagine a scenario in which a corporation's incumbent managers, faced with imminent displacement by a tender offer and fearing investigation of their past misconduct, file a bankruptcy petition merely to insure their continued control of the corporate privilege.").

$\pi$ See Odmark $v$ Westside Bancorporation, Inc, 636 F Supp 552, 556 (W D Wash 1986) ("The Supreme Court has held that former corporate managers could not assert an attorney-client privilege when its invocation would frustrate the Bankruptcy Code's goal of uncovering insider wrongdoing. In the instant case, the legislative history of the controlling [S\&L] statute ... indicates a similar congressional concern and requires a similar denial of the privilege.") (internal citation omitted).

${ }^{78}$ See, for example, Easterbrook and Fischel, Economic Structure at 83 (cited in note 72) (The combination of collective action problems and the easy exit provided by sale of shares makes it difficult for managers to be displaced by shareholders.). See generally Adolph A. Berle and Gardner C. Means, The Modern Corporation and Private Property 244-45 (MacMillan 1933) (management control of proxy machinery).

${ }^{79}$ See note 20. See also United States $v$ Weissman, 1996 US Dist LEXIS 19066, *70-71 (S D NY) (refusing to uphold joint defense agreement between corporation and individual manager accused of wrongdoing because manager concealed information from corporation).

${ }^{80}$ See Garner $v$ Wolfinbarger, 430 F2d 1093, 1103-04 (5th Cir 1970) (holding that the privilege is subject to the shareholders' right to show cause why it should not be invoked).

${ }^{81}$ See, for example, Aronson v Lewis, 473 A2d 805, 813 (Del 1984) (recognizing that the business judgment rule protects board decisions to terminate derivative litigation); Zapata Corp v Maldonado, 430 A2d 779, 785 (Del 1981) (same). See also Easterbrook and Fischel, Economic Structure at 105-06 (cited in note 72) (noting the numerous difficulties faced by plaintiffs seeking to bring a derivative suit). 
wrongdoing where a plaintiff succeeds in bringing such a suit. Additionally, the corporation has a special need to investigate alleged wrongdoing by its own high officers, who otherwise could use the privilege to conceal their activities. ${ }^{82}$

\section{B. Formalism}

Corporate law is replete with formalism. ${ }^{83}$ Based on a variety of legal fictions, corporate law constantly evolves to allow businesses to conduct themselves in a more efficient manner. The corporation's choice of corporate structure depends on a host of business factors. ${ }^{84}$ While these distinctions may be critical in determining the corporation's scope of liability or the amount of tax it must pay, it is less clear why the nature of a corporation's attorney-client privilege should turn on such distinctions. Recognizing this, courts have refused to hold the policy goals of the privilege hostage to the corporate form.

For instance, in both Weintraub and Upjohn, the Supreme Court criticized reliance on the corporate form and implied that the purposes of the attorney-client privilege should not be sacrificed to such rigid formalism. ${ }^{85}$ The Upjohn Court rejected the lower court's "control group" test, which limited the corporate privilege to communications with upper management. ${ }^{86}$ The Court reasoned that such a restrictive test denies the privileges in situations where the policy goal of encouraging corporate

See Gergacz, Attorney-Corporate Client Privilege § 6.02[1] at 6-4 (cited in note 15) ("The inherent danger is the privilege will be used to harm the interests of those it was meant to protect.").

${ }^{*}$ See Jack S. Levin and Martin D. Ginsberg, 1 Mergers, Acquisitions, and Buyouts $\S 106.9$ at 1-23 (Aspen 1997) ("Form is important in corporate acquisitions, perhaps more so than in other areas of taxation.").

st If we see a pattern in the form that corporations choose to adopt, we can be reasonably sure that it is beneficial to shareholders. See Fischel and Easterbrook, Economic Structure at 6-7 (cited in note 72) (Inefficient corporate forms will be punished in capital markets.). Many corporations choose to organize their businesses as subsidiaries. If subsidiaries were banned, or stripped of limited liability, the effect would be to discourage the existence of large corporate organizations. See id at 56-57.

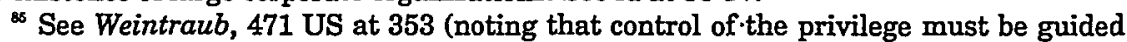
by public policy concerns not mere analogic reasoning); Upjohn, 449 US at 392 (stating that the holding of the court below "frustrate[d] the very purpose of the privilege"). Discussing the impact of $U_{p j o h n}$ on parent-subsidiary issues, one commentator noted, "[i]ts focus was on the reality of corporate organizations and the informational needs of counsel. Thus, the clearest lesson of $U_{p j o h n}$ is its rejection of an organizational focus in favor of a policy approach." Gergacz, Attorney-Corporate Client Privilege $\S 2.02[4][c]$ at 2-16 to 2-17 (cited in note 15).

${ }^{86}$ See 449 US at 392. 
communication requires it. ${ }^{87}$ Similarly, the Weintraub Court ignored the titles of directors and owners. Instead, the Court focused on determining who actually managed the company and what allocation of the waiver power would further the purpose of the Bankruptcy Code. ${ }^{88}$

Outside of the divested subsidiary context, lower courts have embraced this practical approach to the corporate attorney-client privilege. Courts have cited Weintraub when analyzing cases involving government-controlled institutions and equitable receiverships. These courts look beyond the statutory and contextual differences of Weintraub's bankruptcy situation and pragmatically ask who actually exercised management authority. ${ }^{89}$ Courts also have utilized flexible jurisprudence in shareholder derivative suits, often permitting shareholders-with a showing of good cause-to overcome management's control of the privilege. ${ }^{90}$ Furthermore, in other situations involving subsidiaries, courts have shown a willingness to avoid rigid formalism. They do not find an absence of confidentiality when officers of the parent are present at a consultation, despite the fact that they-as members of a different entity-are technically outsiders whose presence should destroy the privilege. ${ }^{91}$

In analogizing the divested subsidiary situation to these cases, the unilateral control courts may have believed that they were following this lead. They neglected, however, to rest their extension of the Weintraub dictum on the underlying policy considerations. This sacrifice of policy to form is illustrated by com-

${ }^{87}$ See id at 391-93.

${ }^{88}$ See Weintraub, 471 US at 353 ("In light of the Code's allocation of responsibilities, it is clear that the trustee plays the role most closely analogous to that of a solvent corporation's management.").

${ }^{8}$ See, for example, Commodity Trading Commission v Standard Forex, 882 F Supp 40, 42-45 (E D NY 1995) (equitable receivership); In re Financial Corporation of America, 119 Bankr 728, 737 (Bankr C D Cal 1990) (FDIC takeover of an S\&L). See also text accompanying notes $44-46$.

${ }^{90}$ See Garner, 430 F2d at 1103-04 (holding that in a shareholder derivative suit, "the privilege [must] be subject to the right of the stockholders to show cause why it should not be invoked"). See also In re Bakalis, 199 Bankr 443, 449-50 (Bankr E D NY 1996) (collecting cases adopting the reasoning of Garner); Robert R. Summerhays, The Problematic Expansion of the Garner v. Wolfinbarger Exception to the Corporate AttorneyClient Privilege, 31 Tulsa L J 275, 287 (1995) (There has been "overwhelming" acceptance of the doctrine in the federal courts and these courts have expanded it to include other situations such as labor unions and partnerships.).

${ }^{91}$ See text accompanying note 54. See also Admiral Insurance Co $v$ United States District Court, 881 F2d 1486, 1493 n 6 (9th Cir 1989) (noting in dicta that Upjohn rejected mechanistic distinctions and thus communications between employees of a subsidiary and corporate counsel for the parent would be protected). 
paring the treatment of divisions to that of subsidiaries. ${ }^{92}$ Under the unilateral control rule, a corporation that sells a division is considered only to have transferred assets. Thus, the parent retains full control of the privilege. Had the parent sold the subsidiary, the parent would have lost control of that same privilege..$^{93}$

The unilateral control rule thus produces precisely the adherence to formalism against which precedent stands. A parent and its subsidiary are limited in their liability toward each other. Thus, because a parent will not be held liable for the subsidiary's legal wrongs, the parent has a reduced incentive to consult regularly with its subsidiary. Therefore, we might expect that the law would want to provide parents and subsidiaries special encouragement to communicate. ${ }^{94}$ The unilateral control rule, however, discourages communication between a parent and its subsidiary.

In effect, corporations that choose to conduct business through a subsidiary rather than a division are penalized if the subsidiary collaborates with the parent in seeking legal advice. While the parent corporation does choose its organizational structure voluntarily, this criticism does not address whether the objectives of the attorney-client privilege are served or impeded by this penalty. Upjohn and other attorney-client cases indicate that form may be sacrificed to advance the policy goals of the privilege. Without taking these policy goals into account, the unilateral courts have accomplished the opposite result. This should cast into doubt their claims of fidelity to Weintraub.

\section{INTENTION OF THE CONTRACTING PARTIES}

A number of the unilateral control courts suggest that the parent selling a subsidiary may contract with the buyer in order to retain control of the privilege.$^{95}$ In this scenario, the unilateral

${ }^{92}$ One unilateral control court explicitly acknowledged that the results would have been different if the parties had structured the deal as an asset sale rather than the sale or divestment of the subsidiary as a whole. See Bass I, 1994 US Dist LEXIS 5474 at *6-7 ("Had Promus wished, it could have sold only Holiday Inn's physical assets, which could have avoided the consequences described in Weintraub.").

${ }^{93}$ See Grand Jury Subpoenas, 734 F Supp at 1213 (noting that the issue was "metaphysical," and suggesting that the parent retained the privilege for documents generated by the division but that the parent had waived it for some material by allowing transfer to the subsidiary), affd in part, vacated in part as Under Seal, 902 F2d at 248 (affirming trial court's finding of waiver).

See text accompanying note 122 .

${ }^{\circ}$ See Sealed Case, 120 FRD 66, 70 (N D Ill 1988) ("It is reasonable then to treat the 
control rule is merely a default rule. ${ }^{96}$ This freedom of contract argument, however, does not necessarily support unilateral control over bilateral control. ${ }^{97}$ It is simple to reverse the default rule and mandate bilateral control. The buyer would then be able to purchase unilateral control over the privilege waiver. If we truly want to capture the intent of the parties, we should ask which default rule is most efficient. This Part demonstrates that the bilateral control rule is the more efficient rule. Therefore, had transactions costs been minimal, the parties to the sale of the subsidiary would have adopted the bilateral control rule.

A default rule, if it is to capture the intent of the parties, should provide the clause to which the parties would have agreed had they addressed the issue at the time they contracted..$^{98}$ Under most imaginable circumstances, the parties would agree to some form of bilateral control. Prior to divestment, both the parent and the subsidiary have an interest in conducting corporate affairs economically and with a full exchange of information between the parent, the parent's counsel, and the subsidiary. ${ }^{99}$ The unilateral control rule unnecessarily frustrates these legitimate objectives. As discussed in Part IV, the unilateral rule can chill conversa-

parties ... as having contracted on the assumption [of unilateral control]. The parties are free to vary this rule by agreement."); Grand Jury Subpoenas, 734 F Supp at 1211 n 5 ("Of course, the parties are free to vary this result by contract. The entity selling control may condition the sale on the purchaser's agreement to grant the seller a veto over any future privilege waivers involving documents generated during the period of the seller's ownership.").

${ }^{96}$ One court suggested, as alternative support for its conclusion, that the language of the sales agreement-which assigned all "rights [and] privileges to the buyer"-represented a specific assignment of the waiver power. See Bass II, 868 F Supp at 620-21. However, this language has been boilerplate in corporate control transactions since before the modern understanding of the corporate privilege. Taken literally, this language would dictate not unilateral authority to waive the privilege by either party, but exclusive control by the subsidiary. The Bass II court did not address this flaw in its argument.

${ }^{97}$ Indeed, it is somewhat puzzling why these courts mention this as an option after going to great lengths to ground their conclusions in Weintraub. The courts also fail to address how a party might craft a term sufficiently clear on the issue to avoid attack.

${ }^{98}$ See Richard A. Posner, Economic Analysis of Law $\S 4.1$ at 93 (Little, Brown 4th ed 1992) ("The task for a court asked to interpret a contract to cover a contingency that the parties did not provide for is to imagine how the parties would have provided for the contingency if they had decided to do so.").

${ }^{93}$ While having separate counsel for a subsidiary would prevent at least some of the negative effects of the unilateral control rule, it is undesirable to force corporate groups to abandon their preferred corporate counsel arrangements and to hire extra lawyers. This is precisely what one of the unilateral courts has recommended. Bass $I, 1994$ US Dist LEXIS 5474 at *8 (suggesting that to avoid waiver a parent might employ separate counsel for its subsidiary and limit sensitive communications to its own staff). 
tions between the parent and the subsidiary and thus jeopardize maximum legal compliance. ${ }^{100}$

In the postdivestment world, either party might anticipate some gains from the ability to waive in favor of a third party. A plaintiff suing both the buyer and the seller of a subsidiary might agree to settle more cheaply with one of the defendants in return for a waiver of the privilege. ${ }^{101}$ Similarly, the government might condition preferential treatment toward one party on waiver against the other party. The party to receive preferential treatment would pursue this agreement regardless of the cost to the other party.

If both parties were defendants in a suit and could communicate easily and cheaply with each other, they would unite to withhold waiver from the plaintiff. In essence, the power of either party to waive in return for a settlement offer-thus increasing the probability that the other party will be forced to litigate $^{102}$-creates a classic "prisoner's dilemma":

\begin{tabular}{l|c|c|}
\multicolumn{1}{c}{} & \multicolumn{2}{c}{ Company 2 } \\
Company 1 & Withhold & Waive \\
\cline { 2 - 3 } Withhold & $(-10,-10)$ & $(-20,-5)$ \\
\cline { 2 - 3 } Waive & $(-5,-20)$ & $(-15,-15)$ \\
\cline { 2 - 3 }
\end{tabular}

Losses: (Company 1, Company 2)

\footnotetext{
${ }^{100}$ These communications may directly benefit the subsidiary, and the subsidiary will in any case profit indirectly if the parent benefits. A recent empirical study of corporate executives, judges, and corporate counsel indicated that communication might indeed be chilled in the absence of the privilege. See Alexander, 63 St John's L Rev at 375-76 (cited in note 74) (finding, through empirical study, that 54.9 percent of attorneys indicated that if the privilege were qualified, upper management would continue to seek legal advice, but the candor of communications and the fullness of documentation would be reduced). See also id at 357-58 (In situations where there was a serious risk of a derivative suit, knowledge that in such suits shareholders could pierce the privilege on a showing of good cause was reported to have chilled communications.).

${ }^{101}$ See Waller v Financial Corp of America, 828 F2d 579, 580-81 (9th Cir 1987) (describing settlement agreement in which former defendant agreed to cooperate in litigation against former codefendant and was promised a share of any judgment).

${ }^{102}$ Waiver of the privilege may not always result in greater litigation. A waiver of the privilege by one party may merely result in a higher settlement by the other. Indeed, by damaging their adversarial position, the waiver may drive the second party towards a settlement. Nevertheless, whether the first party's waiver increases the chance of litigation or increases the settlement, the general point is still valid. Given the ex ante choice, both parties would choose the bilateral control rule.
} 
In most instances, both parties have more to gain by agreeing to withhold waiver than they do by competing to waive. ${ }^{103} \mathrm{Be}$ cause, unlike those in the classic prisoner's dilemma, the parties in the divested subsidiary context can communicate with each other, they will withhold waiver. ${ }^{104}$ And while setting the bilateral rule as a default will costlessly promote this expected result, the unilateral rule will necessitate high transaction costs stemming from bargaining between the parties prior to litigation. ${ }^{105}$

Thus, if they considered the matter while drafting an agreement governing the sale of the subsidiary, both parties would prefer bilateral control. Because, prior to the divestment, the parent need not fear that communications will later be divulged against its will, the bilateral control rule facilitates consultation between parent, subsidiary, and counsel. After the divestment, the bilateral control rule saves the parties the cost of negotiating a mutual withholding of waiver against a third party.

\section{THE UNILATERAL CONTROL RULE CANNOT BE JUSTIFIED BY PUBLIC POLICY CONCERNS}

Even if the buyer and seller of a subsidiary would have chosen the bilateral control rule at the time of contracting, the law must take into account more than the desires of the buyer and seller. It also must take into account the public's interest. Thus, if the bilateral control rule significantly impairs the truthseeking function while failing to facilitate legal consultation (and thus compliance), then the public would be better off under the unilateral control rule. The law could serve the public interest by setting a penalty default in favor of the unilateral control rule, or perhaps even by making the unilateral control rule mandatory. This Part shows that neither of those options is necessary. It examines the public policy effects of the unilateral and bilateral control rules. This examination demonstrates that, first, the bilateral control rule promises to encourage significantly more le-

\footnotetext{
${ }^{103}$ For a general description of the dilemma and the graph, see Douglas G. Baird, Robert H. Gertner, and Randal C. Picker, Game Theory and the Law 33-35 (Harvard 1994). Note that the above graph is a standard representation of the problem. In the settlement context, even the party that unilaterally waived would face some disincentive. This would increase the probability that mutual withholding of waiver would emerge as the preferred term.

${ }^{104}$ See id at 40-41.

${ }^{105}$ Transaction costs in this context would be seriously exacerbated by the parties' difficulties in framing a mutual withholding agreement. Since it is unlikely that the parent and its subsidiary will face the same situation again, reputation costs might not restrain the parties from breaching any informal agreement.
} 
gal consultation (and thus compliance), and second, that in comparison with the unilateral control rule, the bilateral control rule results in only a minor hindrance to the truth-seeking function. However, before engaging in a public policy analysis of the unilateral and bilateral control rules, it is helpful to survey briefly the general justifications for the attorney-client privilege.

\section{A. General Policy Considerations for the Attorney- Client Privilege}

Historically, the attorney-client privilege emerged from nonutilitarian considerations such as the honor of a gentleman. The privilege embodied the notion that "a gentleman never revealed confidences. ${ }^{106}$ Courts have since come to support the privilege primarily on utilitarian grounds: ${ }^{107}$ if a client's communications with an attorney may be used against him, the client will be less likely to seek legal assistance. If he does seek legal assistance, he may withhold critical information, thus reducing the effectiveness of the adversarial system. ${ }^{108}$ For example, the client may withhold information helpful to his case because he wrongly believes that it is damaging. Alternatively, the opponent might eventually discover the information and use it when the client's counsel is unprepared.

These justifications translate, with some modifications, into the corporate context. Corporations, like individuals, should be encouraged to consult candidly with counsel. ${ }^{109}$ Moreover, as the

\footnotetext{
${ }^{106}$ Sexton, 57 NYU L Rev at 445 (cited in note 18), citing Wigmore, 8 Evidence $\S 2290$ at 543 (cited in note 12).

${ }^{107}$ See Sexton, 57 NYU L Rev at 446 (cited in note 18) (describing some debate over its earliest justifications but noting that a utilitarian consensus emerged); Michael L. Waldman, Beyond Upjohn: The Attorney-Client Privilege in the Corporate Context, $28 \mathrm{Wm} \&$ Mary L Rev 473, 480-81 (1987) (noting that courts have shifted to a utilitarian justification for the privilege in the corporate context). See generally Strong, McCormick on Evidence $\S 87$ at 313-17 (cited in note 13) (discussing the differing justifications for the privilege).

${ }^{108}$ See Strong, ed, McCormick on Evidence $\$ 87$ at 314 (cited in note 13). See also Wigmore, 8 Evidence $\$ 2291$ at 546 (cited in note 12) ("If the privilege did not exist at all, every one would be thrown upon his own legal resources. Deprived of all professional assistance, a man would not venture to consult any skillful person, or would only dare to tell his counselor half his case"), citing Greenough $v$ Gaskell, 39 Eng Rep 618, 620 (Ch 1833); Gergacz, Attorney-Corporate Client Privilege § 1.03[1] at 1-9 (cited in note 15) (noting that the privilege promotes efficiency in our legal system).

${ }^{100}$ See, for example, Gergacz, Attorney-Corporate Client Privilege § 1.04[1][b][i] at 1-15 (cited in note 15). Gergacz points out that critics of the corporate privilege fail to recognize the negative societal effect if corporations were chilled from consulting with their lawyers:
}

If Justice requires the interaction of lawyers and business firms, then this justifica- 
Upjohn Court indicated, the complex legal environment in which corporations operate makes the privilege especially valuable to society ${ }^{110}$ This is because without constant consultation with counsel, modern corporations, facing a host of laws and regulations, may not even be aware that they are violating the law. ${ }^{111}$ In the absence of the privilege, corporations might ignore potential problems rather than risk having their own investigative material used against them. Studies have shown that compliance work has gradually become an important part of the corporate lawyer's role. ${ }^{112}$

The privilege does, of course, impair the truth-gathering function of the court. ${ }^{113}$ The court is denied access to privileged communications that might shed light on its inquiries. Nevertheless, the information contained in the communications may otherwise be revealed by diligent discovery. ${ }^{114}$ While the communication is protected by the privilege, the facts underlying it are not. ${ }^{115}$ Moreover, courts and commentators have argued that the

tion is enough to uphold the corporate privilege. The role of corporate counsel is important as a facilitator for the adoption of legal policies by the organization. Therefore, it is in the interests of justice that corporate attorneys be involved in corporate decision making.

Id $\S 1.04[1][\mathrm{b}][\mathrm{i}]$ at $1-16$.

${ }^{110}$ See Upjohn, 449 US at 392 ("In light of the vast and complicated array of regulatory legislation confronting the modern corporation, corporations, unlike most individuals, 'constantly go to lawyers to find out how to obey the law,' particularly since compliance with the law in this area is hardly an instinctive matter.") (citation omitted).

${ }^{11}$ See Gergacz, Attorney-Corporate Client Privilege $\S 104[1][b][i i]$ at 1-16 (cited in note 15) ("What may seem to management to be a natural course of action may inadvertently run afoul of the law. Therefore, legal advice-seeking-preventive law-should be encouraged as a means of conforming business decisions to legal requirements.").

${ }^{122}$ See, for example, Abram Chayes and Antonia H. Chayes, Corporate Counsel and the Elite Law Firm, 37 Stan I Rev 277, 284 (1985) (noting that the increasing complexity of regulations has led to programmatic prevention efforts that have no precedent in traditional corporate law).

${ }^{113}$ See Gergacz, Attorney-Corporate Client Privilege § 1.03[2] at 1-10 (cited in note 15) (By definition, a privilege keeps information from the trier of fact.); Sexton, 57 NYU L Rev at 446 (cited in note 18 ) (" $[E]$ ven its staunchest proponents concede that, whenever the privilege is invoked, otherwise relevant and admissible evidence may be suppressed.").

${ }^{11}$ Wigmore, 8 Evidence $\S 2291$ at 554 (cited in note 12) (concluding that the ultimate loss of information is small in the case of an individual). Because an individual "can be freely interrogated and called to the stand by the opposition and made to disclose on oath all that he knows, it is evident that the disclosure of his admissions made to his attorney would add little to the proof except so far as the client is a person capable of perjuring himself." Id.

${ }^{115}$ Upjohn, 449 US at 395; Gergacz, Attorney-Corporate Client Privilege § 3.02[2][c][i] at 3-41 to 3-42 (cited in note 15). A court in another context has highlighted the problems that arise when parties seek privileged information rather than delve into the facts. See Hewlett-Packard v Bausch \& Lomb, 115 FRD 308, 311 (D Neb 1993) (remarking on the 
plaintiff theoretically will be no worse off, since the communication would not have occurred in the absence of the privilege. ${ }^{116} \mathrm{In}$ practice, some communication would occur even in the absence of the privilege, and its existence increases the costs of discovery for all concerned. However, the mere existence of the corporate attorney-client privilege indicates that courts have deemed that the societal benefits produced by the privilege justify some reduction of the courts' truth-seeking function. ${ }^{117}$

\section{B. Policy Considerations in the Divested Subsidiary Context}

Nothing in the context of the parent-subsidiary relationship alters the policy goal of encouraging communication. In Upjohn, the Supreme Court reasoned that the privilege will encourage communications with counsel, and that these communications will enhance compliance with the law. ${ }^{118}$ Communication between a parent, a subsidiary, and either entity's counsel will similarly encourage compliance. Any rule concerning the privilege in this situation must achieve an appropriate balance between facilitating compliance and preventing excessive frustration of the truth-seeking function. When compared to the unilateral control rule, the bilateral control rule, while not perfect, presents a superior balance of these competing concerns.

The unilateral control rule will chill valuable communication in complex corporate organizations. Corporations organize their legal affairs in a variety of ways. Each subsidiary may have its own independent counsel, or a staff that answers to centralized

"tendency of some lawyers, especially in intellectual property cases, to spend an inordinate amount of time attempting to gain an advantage in the litigation by making use of the adversary attorney's words and opinions .... Preoccupation with efforts to paint opposing counsel into some semantic corner or to take advantage of his choice of terms leads to costly, unproductive, and unseemly disputes.").

${ }^{116} \mathrm{See}$, for example, $U_{p j o h n,} 449$ US at 395 ("Application of the attorney-client privilege to communications such as those involved here, however, puts the adversary in no worse position than if the communications had never taken place."); Stephen A. Saltzburg, Corporate and Related Attorney-Client Privilege Claims: A Suggested Approach, 12 Hofstra L Rev 279, 285 (1984) ("[T]he attorney-client privilege enables clients to communicate with lawyers with the assurance that their communications will not be used by others as additional evidence against them, but does not conceal any information that would have been available to other persons if legal advice had never been sought.").

${ }^{117}$ There is, however, a large body of commentary criticizing the corporate attorneyclient privilege. See Elizabeth G. Thornburg, Sanctifying Secrecy: The Mythologizing of the Corporate Attorney-Client Privilege, 69 Notre Dame L Rev 157, 174-75 (1993) (criticizing the various justifications for corporate attorney-client privilege and advocating its abolition). See also Daniel R. Fischel, Lawyers and Confidentiality, 65 U Chi L Rev 1 (1998) (criticizing attorney-client privilege generally).

${ }^{118}$ See 449 US at 392. 
counsel. In some corporations, legal affairs are entirely centralized, ${ }^{119}$ and may even be concentrated in a subsidiary rather than in the parent. ${ }^{120}$ Regardless of corporate structure, the entities within the corporate group need to consult on legal matters, just as the heads of divisions within a single corporation would need to seek legal advice from the corporate counsel. The Court's reasoning in Upjohn makes it difficult to justify treating the two situations differently. ${ }^{121} \mathrm{~A}$ conference between a parent's legal counsel and an officer of a subsidiary is just as likely to produce socially desirable compliance with the law as the same consultation between counsel and an officer of a division.

The only relevant difference between divisions and subsidiaries is the presence of limited liability. This difference, however, may require efforts to encourage greater communication between a parent and a subsidiary. A corporation is fully liable for any misdeeds by an unincorporated division. Thus, the corporation has strong incentives to take preventive legal measures. The parent of a subsidiary protected by limited liability ordinarily is insulated from liability and thus has less incentive to undertake preventive investigation of its subsidiaries. ${ }^{122}$ Such investigation by the parent may reduce avoidable social harms that result from subsidiary lawbreaking. To further discourage such legal efforts by threatening the loss of the attorney-client privilege would frustrate the policy goals articulated in Upjohn.

If the former subsidiary is willing to waive the privilege in favor of a third party, the unilateral rule would create a gain in truth-seeking; the waiver of any privilege will create a gain in truth-seeking. The more relevant concern is balancing this gain against the societal loss in compliance with the law. Upjohn and its progeny already have struck the balance in favor of privilege. There is nothing unique about the material covered by the unilateral control rule that distinguishes it from material ordinarily protected by the attorney-client privilege. The bilateral control rule merely provides protection to material that would be privileged, but for the divestment of the subsidiary. To the extent that the unilateral control rule provides any gain in truth-seeking, it

\footnotetext{
${ }^{119}$ See, for example, Polycast, 125 FRD at 49; Sealed Case, 120 FRD at 67.

${ }^{120}$ See In re Blinder, Robinson \& Co, Inc, 123 Bankr 900, 902-03 (Bankr D Colo 1991) (discussing, in an attorney disqualification case, a corporate structure in which all legal work was apparently formally done by and in the offices of a subsidiary that produced the bulk of the parent's revenue).

${ }^{121}$ See text accompanying notes 86 and 110 .

${ }^{12}$ See Easterbrook and Fischel, Economic Structure at 50 (cited in note 72) (discussing "moral hazard" of limited liability).
} 
does so randomly. If the subsidiary decides to waive, the nature of the privileged communication or the demands of the particular issue are irrelevant. Under the unilateral control rule, the divested subsidiary could, without justification, reveal communications between a corporation's most senior personnel dealing with extremely sensitive matters. Both courts and an empirical study have indicated that this danger is likely to create disincentives to communicate. ${ }^{123}$

\section{COURTS SHOULD ADOPT THE BILATERAL CONTROL RULE}

The bilateral control rule is the best solution to the problem of privilege waiver by a former subsidiary. The protection of material generated in the presence of officers of another corporation, the allowance made in derivative suits for shareholders to pierce management's invocation of the privilege, and Weintraub and its progeny all demonstrate the willingness of courts to tailor legal doctrines to further the policy goals of the privilege. Recognition of the unique privilege issues involved in parent-subsidiary communication follows logically from this case law. The practical relationship between parent and subsidiary is stronger than the generic "common interest" some courts cite both to protect the privilege and to allow waiver. Communications between parties in this relationship should be granted enough protection to effectuate fully the goals of the privilege.

As demonstrated in Parts III and IV, the bilateral control rule is preferable to the unilateral control rule. The parties themselves would prefer this rule as a method of avoiding the costs of a prisoner's dilemma situation. Society should prefer the bilateral rule because it will avoid chilling communications between a parent and a subsidiary when such communications are necessary to achieve organization-wide compliance with the law.

Communications between parent, subsidiary, and counsel should receive the same bilateral protection that currently is provided to joint defense material. Under this bilateral control rule, either the former parent or subsidiary could assert the

\footnotetext{
${ }^{123}$ See Alexander, 63 St John's L Rev at 266, 414-15 (cited in note 74) (Attention paid to privilege is highest when litigation or transaction is imminent.). See also id at 235-37 (Awareness and effect of privilege appear to increase with rank in a corporation. Attorneys surveyed believed that "awareness of the privilege generally is high at the top of corporate hierarchies and gradually dissipates at lower levels."). Even the test that the Upjohn Court viewed as too underinclusive in its coverage to advance the policy of privilege, the control group test, would cover all communications by higher officers. See $\mathbf{4 4 9}$ US at 390 (describing breadth of control group test).
} 
privilege. However, unless they became direct adversaries in litigation, ${ }^{124}$ neither party could waive the privilege without the permission of the other.

\section{CONCLUSION}

Few courts have explored the question of what doctrine should govern the allocation of control over the attorney-client privilege for communications shared between a parent, a subsidiary, and counsel prior to divestment of the subsidiary. Those courts that have examined the issue have inappropriately granted each party the power unilaterally to waive the privilege against the wishes of the other. Courts should treat such predivestment communications as they would material prepared as part of a joint litigation effort under the joint defense doctrine-neither party should be able to waive without the consent of the other.

The unilateral control rule cannot be justified by reference to the Supreme Court's corporate privilege jurisprudence. The Court has never spoken directly to the question. Moreover, the rationales offered in support of the unilateral control rule exemplify the kind of formalism the Court eschews in this area. Additionally, the unilateral control rule cannot be justified as fulfilling the will of the contracting parties; to the contrary, if transaction costs did not prevent the parties from addressing the issue beforehand, some form of bilateral control would most likely emerge. Lastly, the unilateral control rule cannot be defended as a policy-based penalty default. The policy goal of encouraging corporate communication, articulated by Upjohn and commentators, is better served by the bilateral control rule. Therefore, the

\footnotetext{
${ }^{124}$ In this context, only a suit between the former parent and the subsidiary is directly adversarial. In the suit between the new parent and the old parent, the privilege would remain intact. In applying the bilateral rule of the joint defense doctrine, the unilateral control courts have recognized this. See Bass II, $860 \mathrm{~F}$ Supp at 621 (finding unilateral waiver to new parent, and then examining and rejecting claim of joint defense); Medcom Holding, $689 \mathrm{~F}$ Supp at 846 ("[The new parent, Mecom Holding] brought this action against [the former parent, Baxter] alleging fraud in its sale of the stock of [the subsidiary,] Medcom, Inc. Medcom, Inc. itself is not [Baxter's] adversary; it neither asserts nor defends its own right in this litigation. Accordingly, it could waive the privilege that protects the joint-defense material ....”); Polycast, 125 FRD at 50 (allowing unilateral waiver to new parent, but noting, "If a joint defense privilege were to attach to the conversations, this result might have been different.").
} 
bilateral control rule should be adopted for all communications shared between a parent and a subsidiary. 


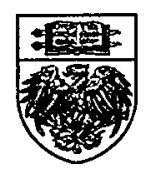

